\title{
Enhanced migration and sequestration of food oily additives into polystyrene oleophilic-hydrophobic-walled containers
}

\section{Migração e sequestro aprimorados de aditivos oleosos para alimentos em recipientes com paredes de poliestireno}

\author{
Temirlan Zhekenov", Dinara Dikhanbayeva², Saltanat Ospanova ${ }^{1}$, Luis Rojas-Solórzano2* (i) \\ ${ }^{1}$ Nazarbayev University, School of Engineering and Digital Sciences, Department of Chemical and Materials \\ Engineering, Nur-Sultan, Akmola - Kazakhstan \\ ${ }^{2}$ Nazarbayev University, Department of Mechanical and Aerospace Engineering, Nur-Sultan - Kazakhstan
}

*Corresponding Author: Luis Rojas-Solórzano, Nazarbayev University, Department of Mechanical and Aerospace Engineering, 53 Kabanbay Batyr, Akmola, 010000, Nur-Sultan - Kazakhstan, e-mail: luis.rojas@nu.edu.kz

Cite as: Zhekenov, T., Dikhanbayeva, D., Ospanova, S., \& Rojas-Solórzano, L. (2021). Enhanced migration and sequestration of food oily additives into polystyrene oleophilic-hydrophobic-walled containers. Brazilian Journal of Food Technology, 24, e2020244. https://doi.org/10.1590/1981-6723.24420

\begin{abstract}
Currently, the high natural oil content in the regular daily diet of a significant segment of the global population has raised deep concern for health authorities worldwide. One example can be soups, which are liquid foods that usually contain high salt levels besides the fat released by the ingredients during the cooking process and the oil that is directly added. This investigation focused on assessing a novel technique to regulate the oil content in soups after being served for consumption. The research aimed to examine the potential reduction of fat in soups by using a non-invasive capillary mechanism created by microchanneling used on the surface of a polystyrene oleophilic/hydrophobic wall in contact with the food to enhance the migration and further sequestration of a fraction of the freely floating oil in these meals.
\end{abstract}

Keywords: Food container; Oil-absorbing technologies; Oil reduction; Polystyrene containers; Microchannels; Surface treatment.

\section{Resumo}

Atualmente, o alto teor de óleo natural na dieta diária regular de um segmento significativo da população global está causando uma grande preocupação para as autoridades de saúde, em todo o mundo. Um exemplo são as sopas, que são alimentos líquidos que costumam conter alto teor de sal, além da gordura liberada pelos ingredientes durante o cozimento e do óleo que é adicionado diretamente. Esta investigação se concentra na avaliação de uma nova técnica para regular o teor de óleo em sopas após serem servidas para consumo. A pesquisa teve como objetivo examinar o potencial de redução de gordura em sopas usando um mecanismo capilar não invasivo, criado pela microcanalização da superfície de uma parede oleofilica/hidrofóbica de poliestireno em contato com o alimento, para aumentar a migração e o posterior sequestro de uma fração do óleo flutuando livremente nessas refeições.

Palavras-chave: Recipiente para comida; Tecnologias de absorção de óleo; Redução de óleo; Recipientes de poliestireno; Microcanais; Tratamento da superfície. 


\section{Introduction}

Excessively fatty foods and unhealthy living habits can cause obesity and many health disorders that may lead to chronic diseases (Subroto et al., 2021; Pan et al., 2021). The increased number of these diseases nowadays indicates the need to decrease our daily food oil concentration.

Moreover, reducing the fat content in our everyday diet is a common concern, especially as the desired amount of oil is difficult to control during food preparation. In addition, regulating the fat content in households and at the industrial level presents many obstacles. At the industrial level, the issue cannot be solved just by decreasing the amount of used fat, but also requires research from a nutritionist regarding the change of taste, proportions of other ingredients, and final calories, which consequently leads to the other changes, such as the product to undergo repackaging (McClements, 2015). Furthermore, the role of Lipid Droplets (LP) is underestimated, especially after considering how they contribute to the texture, flavor profile, visual characteristics, and mouthfeel. Therefore, keeping the food's properties is challenging while decreasing fat content in the production stage (Bayarri et al., 2007). These measures require a certain amount of investments and bring additional expenses, which food production companies do not meet. Additionally, due to the different functions of fat droplets in food quality, a unique strategy to replace the fat or reduce its amount cannot be used (McClements, 2015). Several techniques must be applied at both production and post-production stages.

The technology proposed in this investigation was based on using microchannels in the inner surface of a polystyrene beverage container. In fact, this microchannel technology intends to reduce the time of oil separation and eliminate the need for additional equipment. In addition, there is no need to take additional action to remove the oil, as the oil is expected to be absorbed by the microchannels during food serving.

Hence, our research aimed to evaluate the effectiveness of a novel oil migration and sequestration technique based on the capillary effect of radially-engineered microchannel cuttings made on the oleophilic/hydrophobic surface of a polystyrene food container to control the amount of free buoyant oil. For this purpose, experiments were conducted using commercial polystyrene beverage containers, organic oil, and water.

\subsection{Background of the study}

Within the limited examples of oil sequestration techniques for soups used in the food industry, one of the most common techniques used is the oil filter based on oil buoyancy on water (Amazon, 2019). Other methods are based on manual or automated oil collection from the soup surface (Food and Agriculture Organization, 1992). Furthermore, the technique used in households consists of moving the oily liquid stock from one container to another and waiting for the liquid to settle (Cook's Illustrated, 2019).

The existing methods of controlling the fat content in the served food are still far from being widely spread among the population, perhaps due to the devices' intrusive character, the extra effort needed, and the time required to operate them. In addition, the fraction of the oil captured by devices currently in the market is hardly considered to be controlled or predicted with precision.

Soups are one of the most widely spread dishes among different cultures (Ma, 2015). Although the soup preparation methods vary significantly, it is commonly accepted that the dish may contain more liquid than solid food to be classified as a soup (Goltz, 2008). According to the World Health Organization (WHO), the butter and meat-fatty saturated oils added to soups may cause harmful effects on human beings' health. Excess of fat in the usual diet might lead to obesity, diabetes, heart disease, strokes, and increased cholesterol level, which in turn typically leads to blockage of blood vessels and a high risk of heart attack (World Health Organization, 2019; Arthur et al., 2021).

Additionally, according to a 2017 report made by the Global Burden of Diseases, Injuries, and Risk Factors Study (GBD), 15 risks related to a high-fat diet greatly impacted mortality because of diabetes, cancer, or cardiovascular diseases. This risk evaluation examines and includes 84 risks linked with metabolism, environment, location, and other factors over 195 countries (GBD Risk Factor Collaborators, 2018). 
Hence, developing new methods for controlling the fat content in regular foods such as soups depending on each person's needs is of great importance. Moreover, an added benefit from controlling the fat level in the served food might be the satisfaction of each individual's food habits.

An overview of existing oil-absorbing technologies in the petroleum industry, which do not require extensive treatment efforts rather than contact, might assist in finding the possibilities for creating similar techniques to be implemented during food consumption. The examples of oil collecting and sequestrating techniques are in extended use. They include the dispersion of oil with additives, bioremediation of oil, and sponge-like materials, among others (Korhonen et al., 2011). Even though using these technologies in the petroleum industry is a growing trend, their use in the food industry is still questionable, as there is a lack of evidence about their effects on human health, which has not been demonstrated. Nevertheless, it is essential to remark that optimism exists around the future of silica aerogels, which is the standard type of aerogel used in the food industry (U.S. Food and Drug Administration, 2019).

While the aerogel oil-absorbing technique uses a porous media in which the oil droplets are being mechanically pulled in, it is noted that the oil filters are mainly based on the differences in liquid density (Zheng et al., 2014). One of the significant drawbacks of the aerogel technology in organic oil migration from food might be the time of absorption and the implementation, which may lead to dissatisfaction of users (Zheng et al., 2014). The oil filters do not require much time to operate. However, it is undesirable to apply any additional device since it surely would change every day diner habits and limit its use.

On the other hand, polystyrene fiber is well known for being oleophilic and hydrophobic, and it is widely used in oily water treatment (Doan et al., 2019). Furthermore, sustainability reasons are forcing brands in packaging to use expanded polystyrene. The attractiveness of polystyrene to the market is associated with its ease of recycling and environmental friendliness. It is predicted that the global polystyrene market for packaging will increase at a Compound Annual Growth Rate (CAGR) of 6\% until 2023, reaching USD 1.57 billion (British Plastics Federation, 2012). Moreover, one of the main segments is food and beverage packaging. Previous studies could show that using hydrophobic-oleophilic fibers with an increased surface area may result in excellent oil sorption performance (Korhonen et al., 2011; Lee et al., 2013). However, increasing the oilabsorption properties of polystyrene requires complex electrospinning and centrifugal spinning processes of porous fibers (Doan et al., 2019; Wu et al., 2012; Lin et al., 2012; Lee et al., 2013).

\section{Materials and methods}

The experiments were designed to evaluate the potential enhancement in oil sequestration obtained by introducing a varying number of equally-spaced single-depth radial microchannels along the inner wall of a standard polystyrene bowl containing a typical soup. Therefore, one dependent variable and one independent variable were considered in the analysis, and the other parameters were kept constant.

Hence, during the experimental procedure, a pre-heated mixture of $3.6 \mathrm{~mL}$ of sunflower oil and $314 \mathrm{~mL}$ of water simulated the soup meal in a $460 \mathrm{~mL}$-capacity commercial bowl of polystyrene (Modi, 2019). The mixture temperature was set to $70^{\circ} \mathrm{C}$ for all the experiments, as this is one of the most popular serving temperatures for soups (Kim et al., 2015). During all the experiments, the air relative humidity was measured with a home-made alcohol hygrometer and maintained between $65 \%$ to $-78 \%$. Water was boiled using a kettle, and a graduated $(100 \pm 1 \mathrm{~mL})$ cylinder was used to measure the desired volume. Water was poured into the soup container when the temperature cooled down to the desired value $\left( \pm 1^{\circ} \mathrm{C}\right)$, and it was measured with a mercury thermometer. The oil amount was measured using a METTLER TOLEDO (USA) XP6U Automated-S Ultra-microbalance electronic balance. The mass of the mixture itself was measured using an A\&D Weighing (Japan) HR202i balance with a maximum uncertainty of $\pm 1 \mathrm{mg}$ to obtain the correct ratio of water and oil.

Furthermore, an empty bowl was weighted several times to determine the error and range of reading variation from the electronic balance. The time for settling up the stable reading was measured by taking intermediate readings 
every $30 \mathrm{~s}$ up to $15 \mathrm{~min}$ for each trial. Thus, the time for stabilizing the electronic balance reading was $5 \mathrm{~min}$, after each time, with a confidence interval of $95 \%$. Hence, the total weight per sample resulted in $4383.858 \pm 0.780 \mathrm{mg}$, the deviation of which was adequate. Figure 1 presents the schematic overview of the experimental procedure, including the hydrophobic and oleophilic baselines for the original polystyrene bowl (i.e., without microchannels).

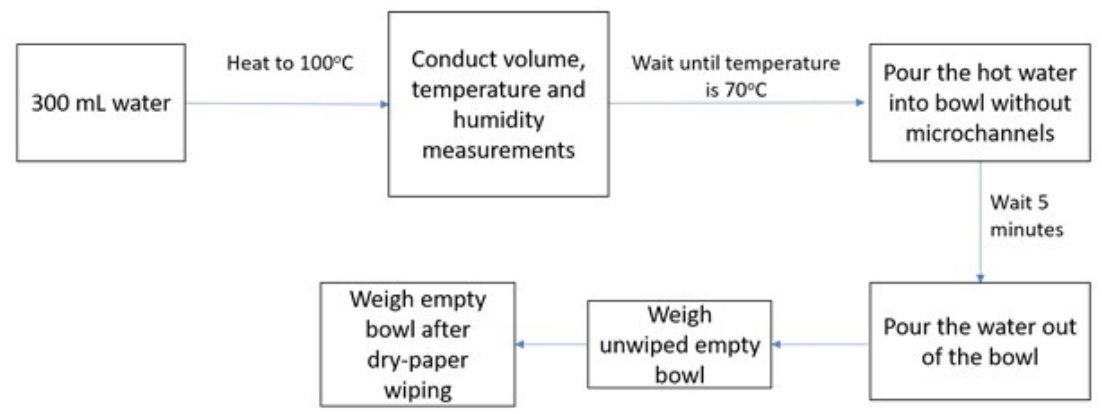

(a)

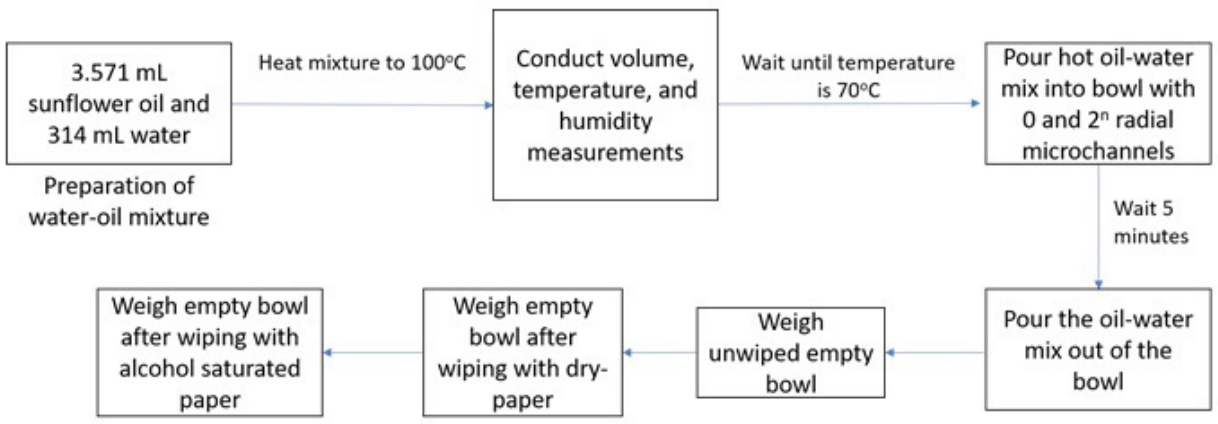

(b)

Figure 1. Scheme of the experimental procedure to measure absorption by the wall of the bowl of (a) water (hydrophobic baseline); (b) oil (oleophilic baseline and oil from the mixture).

The $460 \mathrm{~mL}$-capacity beverage bowl has a bottom diameter of $11.4 \mathrm{~cm}$ and a top open circular edge diameter of $20 \mathrm{~cm}$. On the beverage bowl's inner surface, tiny radial channels were opened using a small surgical scalpel, as shown in Figure 2.

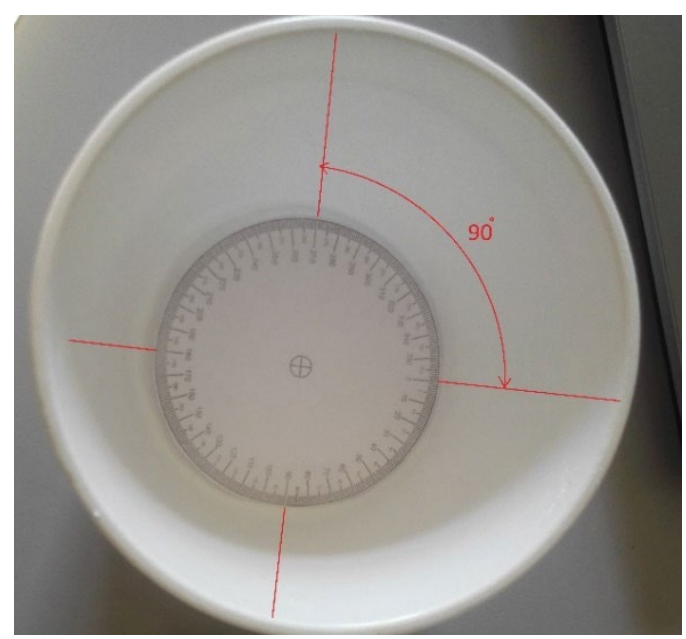

Figure 2. Radial cutting guiding lines. 
The microchannels were made using a $360 \mu \mathrm{m}$-width scalpel with an approximate incision covering about half of the wall's thickness. With the help of two circular protractors placed at the bottom and the top edge of the beverage bowl and a ruler to connect both sides, the cuttings were made at significantly precise angle intervals of $90,45,22.5$, and 11.25 degrees \pm 1 degree (Figure 2), which resulted in a total of $4,8,16$, and 32 microchannels, respectively. The channels extend from the periphery of the bottom circle to the very top edge of the bowl.

The scalpel width and the maximum number of microchannels were selected to guarantee significant capillary absorption of the bowl wall without compromising the Mechanical Integrity (MI) of this container. For instance, the bowl shape suffered significant deformation when filled with the hot liquid beyond 32 microchannels, jeopardizing our safety during hand manipulation.

The microchannels were done with a scalpel by hand, keeping the same pressure on each cut, minimizing the level of uncertainty of the microchannel's depth. The same person executed all the superficial cuts in all cases, letting the scalpel advance just pressed by the hand's weight.

First, experiments were executed to demonstrate the hydrophobic-oleophilic nature of the walls of polystyrene bowl without microchannel, acting as a baseline case. The hydrophobic tests were run using boiled water alone. In contrast, the oleophilic baseline and further oil sequestration tests with microchannels were run using a mix of hot water-sunflower oil, mimicking the typical characteristics of a regular soup. Thus, a hot water-sunflower oil mix at $70{ }^{\circ} \mathrm{C}$ was prepared by combining $3.57 \mathrm{~mL}$ of sunflower oil $\left(3.17 \mathrm{~g}\right.$ at $70{ }^{\circ} \mathrm{C}$, according to properties determined in Esteban et al., 2012) and $314 \mathrm{~mL}$ of water $\left(307 \mathrm{~g}\right.$ at $\left.70{ }^{\circ} \mathrm{C}\right)$. The temperature was controlled with a mercury thermometer along the experimental process.

The hydrophobicity baseline experiment was repeated 11 times, while each experiment with the watersunflower oil mix was repeated five times for statistical validity of the results.

In all cases, the measurements were made after the hot water or water-oil mix remained for $5 \mathrm{~min}$ in the bowl. Then, the liquid was poured out, and the container was placed on a scale to determine any weight gain. The weight readings were done after wiping the bowl with dry absorbent paper tissue (commercial highabsorbency single-layer paper towels, made of $100 \%$ cellulose). Furthermore, three consecutive dry-wiping steps using the same absorbent paper tissue were done. One last wiping step was done with an ethanolsaturated absorbent paper tissue to wipe off any remaining oil on the surface of the walls. Significant effort was made to controlling potential sources of error in the measurements, and special attention was devoted to the presentation of uncertainties in the discussion of results.

\section{Results and discussion}

First tests were conducted on several samples of the beverage container without microchannels as a benchmark to determine the baseline case of the naturally expected hydrophobic-oleophilic action of the original, untreated bowl wall. Secondly, tests were performed to determine the oil absorption under handmade microchannels.

\subsection{Baseline: hydrophobic and oleophilic properties of the bowl}

The capacity of the polystyrene bowl to absorb water was assessed by pouring $300.0 \pm 0.1 \mathrm{~mL}$ of hot water at $70{ }^{\circ} \mathrm{C}(293.3 \mathrm{~g})$ into the original bowl with an initial (dry) mass given by $\mathrm{m}_{\text {bowl }}$. After $5 \mathrm{~min}$, the water was drained from the bowl, and the residual water mass left after emptying and dry-wiping the bowl was determined by weighing the bowl again ( $m_{\text {bowl,new }}$ ) using the electronic balance. The droplets left at the surface were carefully removed by soft wiping the wall using the absorbent paper tissue. Table 1 presents the results confirming the hydrophobic nature of the polystyrene bowl, as an average of $0.022 \%$ of water absorption was registered, which was within the error of the electronic balance. Minor errors and uncertainties did not significantly affect the results, as these were consistent throughout the 11 repetitions of the experiment. Nevertheless, the authors recognize that using a $100 \mathrm{~mL}+0.1 \mathrm{~mL}$ container to add $300 \mathrm{~mL}$ of water to the bowl may have added a small error in the total measured volume (it is recommended to use a larger container of water for future replications). 
Table 1. Measurements of hydrophilic properties of polystyrene cups: water absorption capacity.

\begin{tabular}{ccccc}
\hline Trial & Humidity $\%$ & $\mathbf{m}_{\text {bowl }}(\mathbf{m g})$ & $\mathbf{m}_{\text {bowl, new }}(\mathbf{m g})$ & $\Delta \mathbf{m}(\mathbf{m g})$ \\
\hline 1 & 78 & $4344 \pm 1$ & $4426 \pm 1$ & $82 \pm 2$ \\
\hline 2 & 78 & $4083 \pm 1$ & $4265 \pm 1$ & $182 \pm 2$ \\
\hline 3 & 78 & $4518 \pm 1$ & $4641 \pm 1$ & $66 \pm 2$ \\
\hline 4 & 61 & $4253 \pm 1$ & $4320 \pm 1$ & $15 \pm 2$ \\
\hline 5 & 61 & $4197 \pm 1$ & $4213 \pm 1$ & $27 \pm 2$ \\
\hline 6 & 61 & $4389 \pm 1$ & $4416 \pm 1$ & $70 \pm 2$ \\
\hline 8 & 72 & $4384 \pm 1$ & $4454 \pm 1$ & $22 \pm 2$ \\
\hline 10 & 72 & $4460 \pm 1$ & $4482 \pm 1$ & $28 \pm 2$ \\
\hline 11 & 72 & $4247 \pm 1$ & $4275 \pm 1$ & $62 \pm 2$ \\
\hline Average: & 72 & $4475 \pm 1$ & $4537 \pm 1$ & $13 \pm 2$ \\
\hline
\end{tabular}

$\mathrm{m}_{\text {bowl }}$ : original bowl with an initial (dry) mass; $\mathrm{m}_{\text {bowl,new: }}$ residual water mass left after emptying and dry-wiping the bowl

Furthermore, the oleophilic tests on the original polystyrene bowl were carried out by pouring a hot mix (at $70{ }^{\circ} \mathrm{C}$ ) of $3.6 \mathrm{~mL} \pm 0.1 \mathrm{~mL}\left(3.2 \mathrm{~g}\right.$ at $\left.70{ }^{\circ} \mathrm{C}\right)$ sunflower oil and $314.0 \mathrm{~mL} \pm 0.1 \mathrm{~mL}\left(307 \mathrm{~g}\right.$ at $\left.70{ }^{\circ} \mathrm{C}\right)$ water. This mix of hot oil and water was used for the rest of the experiments. This is typically the proportion for chicken noodle soup, which is considered one of the most widespread soups in the world (United States Department of Agriculture, 2019a, 2019b). After 5 minutes, the water-oil mix was drained, and the bowl's inner surface was wiped several times to completely clean the surface and quantify the oil trapped in the pores of the uncut bowls. Figure 3 shows the oleophilic test results in each of the 5 trials after the subsequent wiping steps compared to the original amount of sunflower oil in the mix. The $\mathrm{x}$-axis represents the number of experimental trials. The y-axis represents the oil mass in the original mix and the remaining amount on the bowl surface after pouring out the mix and passing through several wiping stages. Three sequential dry wiping sessions followed by one ethanol-wet wiping session were conducted and depicted in trendlines with their markers in Figure 3. The bowl walls were wiped from bottom to top and in a clockwise direction. The bowl surface's oleophilic behavior was evident, as there was substantial oil retention even after the first dry wiping step. Moreover, it could be observed that an average amount of $51 \pm 1 \mathrm{mg}$ of sunflower oil was systematically absorbed by the bowl walls after the final wiping stage with an ethanol-wet tissue, corresponding to $1.6 \%$ of the total amount of sunflower oil present in the original mixture. The amount of oil sequestrated by the container walls in the baseline test was considered the reference value to determine the enhanced amount of oil absorbed through the microchannels on the walls.

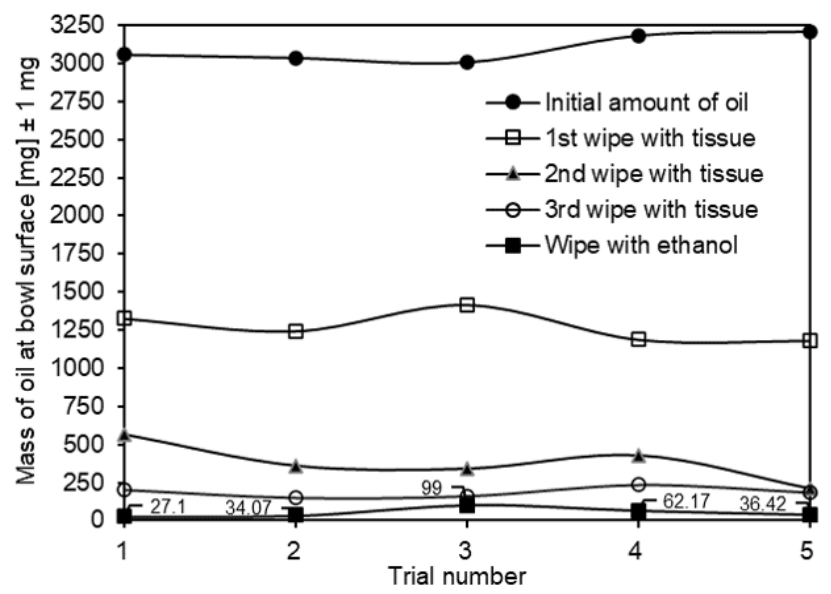

Figure 3. Mass of oil absorbed by the bowl surface without microchannels after pouring out the mixture for each of the trials. 


\subsection{Microchannel oil capturing}

Figure 4 shows the results for the experimental runs with different configurations of the microchannels.

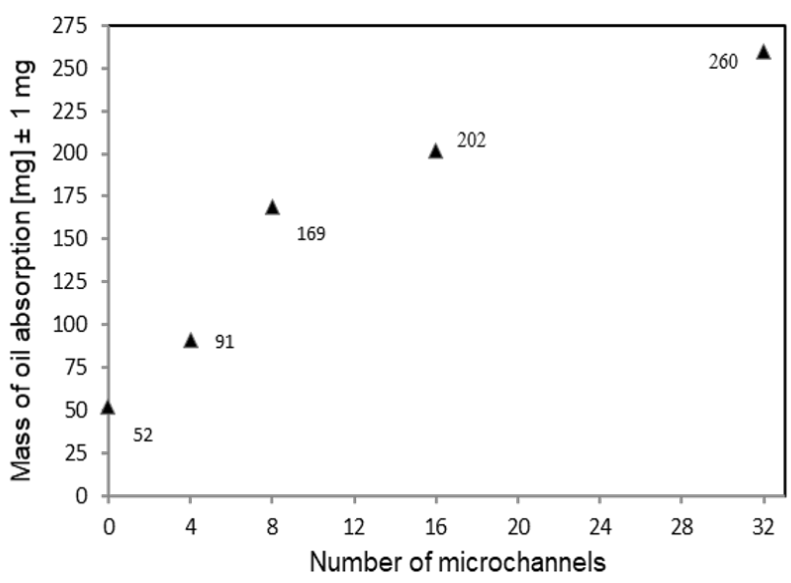

Figure 4. Average mass of oil sequestrated versus the number of microchannels in the bowl.

Our study found that the number of microchannels (four, eight, 16, and 32 microchannels made in the bowl's inner surface) directly impacts the amount of oil sequestrated from the oil-liquid mixture. Hereafter, the amount of oil sequestrated is considered using the base case as a reference to assess the migration. For four (4) microchannels (90 degrees of separation), the amount of oil absorbed was between $1.6 \%$ and $2.9 \%$ of the initial oil present in the mixture. The most significant increase of oil absorption happened when the number of microchannels was doubled from four to eight ( 90 to 45 degrees of separation, respectively), which led to almost double the amount of absorption. Any further increase in the number of microchannels led to a moderate rise in absorbed oil, reaching up to $8 \%$ of the initial oil mass at 32 microchannels, as shown in Figure 4. Moreover, the bowl's mechanical integrity was compromised when the number of microchannels in the bowl was increased beyond 32. The oil migration increased by $43.1 \%, 46.2 \%$, and $16.2 \%$ when the number of microchannels increased from 0 to four, from four to eight, and from eight to 16 , respectively.

Although the microchannels were done manually, special care was placed to minimize human errors and guarantee uniformity, as much as possible, regarding the depth of each channel. Results were consistent in all experiments, with no outliers, proving the effectiveness of our approach. Nevertheless, future work is recommended to introduce feasible and affordable techniques to guarantee precise control of the microchannels' incision depth.

\section{Conclusions}

Oleophilic-hydrophobic polystyrene food containers' enhanced oil migration and sequestration capacity were assessed by producing microchannels on the inner surface in contact with hot water-oil soup-like mixtures. The analysis of the experiments led to the following concluding remarks:

1. Radially-practiced $360 \mu \mathrm{m}$-width microchannels along the inner surface of the soup container proved to be an effective way to pull in a significant amount of buoyant oil in proportion to the number of channels in contact with the mixture. Nevertheless, future work could address the potential effects of thinner and thicker microchannels and their practical limits;

2. The most significant increase in the volume of oil sequestrated occurs within the first eight microchannels added. Nevertheless, when the number of microchannels was increased up to 32 , the total amount of oil absorbed by the wall surface reached $8 \%$ of oil in the initial mixture;

3. The tests were limited to a maximum of 32 microchannels to guarantee the mechanical integrity of the bowl wall. 


\section{Acknowledgements}

This research paper was made possible through the enormous help and support from the academic staff of the School of Engineering of Nazarbayev University. The authors would like to show deep gratitude towards Dr. Zhumabay Bakenov, Nurzhan Umirov, and the Institute of Battery Research group for supporting our work throughout the research project process with their encouragement, advice, and help. Moreover, we would like to thank them for kindly providing us with their laboratory facilities for conducting all the experiments. This research project would not have been possible without their support.

\section{References}

Amazon. (2019). Retrieved in 2019, May 24, from https://www.amazon.com/SM-SunniMix-Stainless-SeparatorSupplies/dp/B07JDPK6QM

Arthur, R., Dannenberg, A., Kim, M., \& Rohan, T. (2021). The association of body fat composition with risk of breast, endometrial, ovarian and colorectal cancers among normal weight participants in the UK Biobank. British Journal of Cancer, 124(9), 1592-1605. PMid:33723399. http://dx.doi.org/10.1038/s41416-020-01210-y

Bayarri, S., Smith, T., Hollowood, T., \& Hort, J. (2007). The role of rheological behavior in flavor perception in model oil/water emulsions. European Food Research and Technology, 226(1-2), 161-168. http://dx.doi.org/10.1007/s00217-006-0521-8

British Plastics Federation - BPF. (2012). Expanded Polystyrene (EPS) and the environment. Retrieved in 2019, May 24, from http://www.eps.co.uk/pdfs/eps_and_the_environment.pdf

Cook's Illustrated. (2019). Fat separators. Retrieved in 2019, May 24, from https://www.cooksillustrated.com/equipment_reviews/1725fat-separators/

Doan, H., Nguyen, D., Vo, P., Hayashi, K., Kinashi, K., Sakai, W., Tsutsumi, N., \& Huynh, D. P. (2019). Facile and scalable fabrication of porous polystyrene fibers for oil removal by centrifugal spinning. ACS Omega, 4(14), 15992-16000. PMid:31592142. http://dx.doi.org/10.1021/acsomega.9b02091

Esteban, B., Riba, J., Baquero, G., Puig, R., \& Rius, A. (2012). Characterization of the surface tension of vegetable oils to be used as fuel in diesel engines. Fuel, 102, 231-238. http://dx.doi.org/10.1016/j.fuel.2012.07.042

Food and Agriculture Organization - FAO. (1992). Manuals of food quality control. Washington: FAO. Retrieved in 2019, May 24, from http://www.fao.org/3/T0610E/T0610E.pdf

GBD Risk Factor Collaborators. (2018). Global, regional, and national comparative risk assessment of 84 behavioural, environmental and occupational, and metabolic risks or clusters of risks for 195 countries and territories, 1990-2017: A systematic analysis for the Global Burden of Disease Study 2017. Lancet, 392(10159), 1923-1994. PMid:30496105.

Goltz, E. (2008, november 9). Soup vs. stew: Difference in details. The Journal Gazette. Retrieved in 2019, May 24, from http://web.archive.org/web/20110811025536/www.journalgazette.net/apps/pbcs.dll/article?AID=/20081109/FEAT0103/811090311

Kim, J., Samant, S., Seo, Y., \& Seo, H. (2015). Variation in saltiness perception of soup with respect to soup serving temperature and consumer dietary habits. Appetite, 84, 73-78. PMid:25265155. http://dx.doi.org/10.1016/j.appet.2014.09.018 Korhonen, J., Kettunen, M., Ras, R., \& Ikkala, O. (2011). Hydrophobic nanocellulose aerogels as floating, sustainable, reusable, and recyclable oil absorbents. ACS Applied Materials \& Interfaces, 3(6), 1813-1816. PMid:21627309. http://dx.doi.org/10.1021/am200475b

Lee, M., An, S., Latthe, S., Lee, C., Hong, S., \& Yoon, S. (2013). Electrospun polystyrene nanofiber membrane with superhydrophobicity and superoleophilicity for selective separation of water and low viscous oil. ACS Applied Materials \& Interfaces, 5(21), 10597-10604. PMid:24090059. http://dx.doi.org/10.1021/am404156k

Lin, J., Shang, Y., Ding, B., Yang, J., Yu, J., \& Al-Deyab, S. (2012). Nanoporous polystyrene fibers for oil spill cleanup. Marine Pollution Bulletin, 64(2), 347-352. PMid:22136762. http://dx.doi.org/10.1016/j.marpolbul.2011.11.002

Ma, G. (2015). Food, eating behavior, and culture in Chinese society. Journal of Ethnic Foods, 2(4), 195-199. http://dx.doi.org/10.1016/j.jef.2015.11.004

McClements, D. (2015). Reduced-fat foods: The complex science of developing diet-based strategies for tackling overweight and obesity. Advances in Nutrition, 6(3), 338S-352S. PMid:25979507. http://dx.doi.org/10.3945/an.114.006999

Modi. (2019). Retrieved in 2019, May 24, from http://www.modicup.com/files/modi2011.pdf

Pan, X., Wang, L., \& Pan, A. (2021). Epidemiology and determinants of obesity in China. The Lancet. Diabetes \& Endocrinology, 9(6), 373-392. PMid:34022156. http://dx.doi.org/10.1016/S2213-8587(21)00045-0

Subroto, E., Indiarto, R., Djali, M., \& Rosyida, H. D. (2021). Production and application of crosslinking- modified starch as fat replacer: A review. SSRG International Journal of Engineering Trends and Technology, 68(12), 26-30. http://dx.doi.org/10.14445/22315381/IJETT-V68112P205

U.S. Food and Drug Administration - FDA. (2019). Generally Recognized as Safe (GRAS). Retrieved in 2019, May 24, from https://www.fda.gov/food/food-ingredients-packaging/generally-recognized-safe-gras

United States Department of Agriculture - USDA. (2019a). USDA National Nutrient Database for Standard Reference: USDA ARS. Retrieved in 2019, May 24, from https://www.ars.usda.gov/northeast-area/beltsville-md-bhnrc/beltsville-human-nutritionresearch-center/nutrient-data-laboratory/docs/usda-national-nutrient-database-for-standard-reference/ 
United States Department of Agriculture - USDA. Agricultural Research Service - ARS. (2019b). USDA national nutrient database for standard reference: USDA ARS. Retrieved in 2019, May 24, from https://www.ars.usda.gov/northeastarea/beltsville-md-bhnrc/beltsville-human-nutrition-research-center/nutrient-data-laboratory/docs/usda-national-nutrientdatabase-for-standard-reference/

World Health Organization - WHO. (2019). Healthy diet. Rome: FAO. Retrieved in 2019, May 24, from https://www.who.int/news-room/fact-sheets/detail/healthy-diet

Wu, J., Wang, N., Wang, L., Dong, H., Zhao, Y., \& Jiang, L. (2012). Electrospun porous structure fibrous film with high oil adsorption capacity. ACS Applied Materials \& Interfaces, 4(6), 3207-3212. PMid:22620260. http://dx.doi.org/10.1021/am300544d

Zheng, Q., Cai, Z., \& Gong, S. (2014). Green synthesis of polyvinyl alcohol (PVA)-cellulose nanofibril (CNF) hybrid aerogels and their use as super absorbents. Journal of Materials Chemistry A, Materials for Energy and Sustainability, 2(9), 3110-3118. http://dx.doi.org/10.1039/C3TA14642A 